\title{
Carotid Blowout Syndrome に対する血管内治療
}

$\begin{array}{lllllllll}\text { 足 } & \text { 立 明 彦 } & \text { 小 } & \text { 林 } & \text { 一 } & \text { 渡 } & \text { 邊 義 之 } & \text { 米山サーネキー智子 } \\ \text { 早 坂 典 弘 } & \text { 鈴 } & \text { 木 } & \text { 誉* 岡 本 美 孝* 佐 伯 直 勝 }\end{array}$

\section{Endovascular Treatment of Radiation-induced Carotid Blowout Syndrome : Report of Two Cases} by

Akihiko Adachi, M.D., Eiichi Kobayashi, M.D., Ph. D., Yoshiyuki Watanabe, M.D., Tomoko Yoneyama-Sarnecky, M.D., Ph. D., Michihiro Hayasaka, M.D., Homare Suzuki, M.D., Ph. D. *, Yoshitaka Okamoto, M.D., Ph. D. ${ }^{*}$, and Naokatsu Saeki, M.D., Ph. D. from

Department of Neurosurgery and ${ }^{*}$ Otorhinolaryngology/Head and Neck Surgery, Graduate School of Medicine, Chiba University

Background : Carotid Blowout Syndrome (CBS), or Carotid Artery Rupture (CAR), is a delayed complication with potentially fatal consequences occurring after the implementation of radiotherapy on head and neck tumors. In this report we describe two patients received endovascular treatment for severe hemorrhagic CBS developing 36 and 2 years, respectively, after radiotherapy. Both patients survived and responded positively to treatment.

Methods : Case 1 was an 80-year-old woman found with minor hemorrhage near the bifurcation of the common carotid artery, 36 years after neck irradiation. She experienced frequent hemorrhagic events during the following years. Six years after the initial discovery of bleeding, she experienced massive hemorrhage, lapsed into shock, and was admitted to an Emergency Room. Connective tissue around the carotid artery was largely exposed due to neck skin defect. After hemorrhage was halted by manual compression, transient hemostasis was achieved with coil embolization of the aneurysm presumed to be the source of bleeding. Recurrent hemorrhage developed two weeks later with unraveled coil mass extrusion. Parent artery occlusion was performed by endovascular trapping, achieving permanent hemostasis. Case 2 presented massive nasal bleeding originating from the petrous segment of the internal carotid artery, 2 years after having been treated with heavy particle irradiation for olfactory neuroblastoma. Ischemic tolerance was confirmed by balloon occlusion test. Based on previous experiences, the bleeding was immediately halted by endovascular trapping.

Result : Both patients were subsequently discharged, free of new neurological symptoms.

Conclusion: Emergent hemostatic treatment is required in CBS developing severe hemorrhage. However, within irradiation fields, temporal embolization devices hardly lead to complete resolution. This is due to the deteriorated condition of the vascular wall incapable to enduring the expansion power of coils, stents or balloons. Bypass grafting is also difficult, due to the fragile surrounding tissue. Although, the application of sufficientlylong covered stents is anticipated in the future, parent artery embolization is often required to save the patient's life even when the occlusion test is impossible. In such cases, endovascular trapping out of irradiation fields is the most reliable and efficacious treatment for achieving permanent hemostasis.

(Received October 5, 2010; accepted February 1, 2011)

Key words : carotid blowout syndrome, radiation therapy, head and neck tumor, coil embolization, endovascular trapping

Jpn J Neurosurg（Tokyo）20:597-603, 2011

\footnotetext{
千葉大学大学院医学研究院脳神経外科 / T260-8670 千葉市中央区亥鼻 1-8-1〔連絡先 : 足立明彦〕

Address reprint requests to: Akihiko Adachi, M.D., Department of Neurosurgery, Graduate School of Medicine, Chiba University,

1-8-1 Inohana, Chuo-ku, Chiba-shi, Chiba 260-8670, Japan

*同耳鼻咽喉科・頭頸部腫瘍学
} 


\section{緒 言}

Carotid blowout syndrome (CBS) または carotid artrery rupture（CAR）は，頭澒部腫愓に対する放射線治療後に 数年〜数十年経過してから発生し, 動脈破裂を引き起こ す致死的疾患として知られている，治療は，可能なら虚 血而性を確認したうえでの母動脈塞栓が基本であるが, 緊急性が高く, ショックや意識障害などにより正確な閉 塞試験が困難であり, 治療に難啮する場面が多い. 今回, 総䅡動脈分岐部の CBS に対し緊急処置として血管内治 療を施行し, 再出血を生じるも追加治療にて救命しえた 症例を経験した（症例 1). 発症メカニズムと治療法に関 しては議論も多く, 内頝動脈錐体部の CBS の例（症例 2）とともに，若干の文献的考察を交元報告する.

\section{症例提示}

\section{【症例 1]}

患 者: 80 歳, 女性

主 訴: 顼部頝動脈からの大量出血

既往歴: 37 歳時, 左䅡部覀性腫貆に対し摘出術および 放射線治療を施行した，病理および放射線計画は記録が なく，治療詳細は不明であった。

現病歴：73 歳時より左頝部の皮膚欠損部から少量の出 血があり皮膚科を受診した。幸い家人に看護師がおり， 用手圧迫にて止血が得ら机ていたが，その頃より嗄声・ 咽頭痛が出現した。当院耳鼻咽喉・頭頸部外科にて潰瘍 化かつ瘢痕化した軟部組織の生検を行うも悪性/再発所 見は認めず，外来でフォローされていた。

74 歳時に，皮膚欠損部より大量出血があり，他科にて
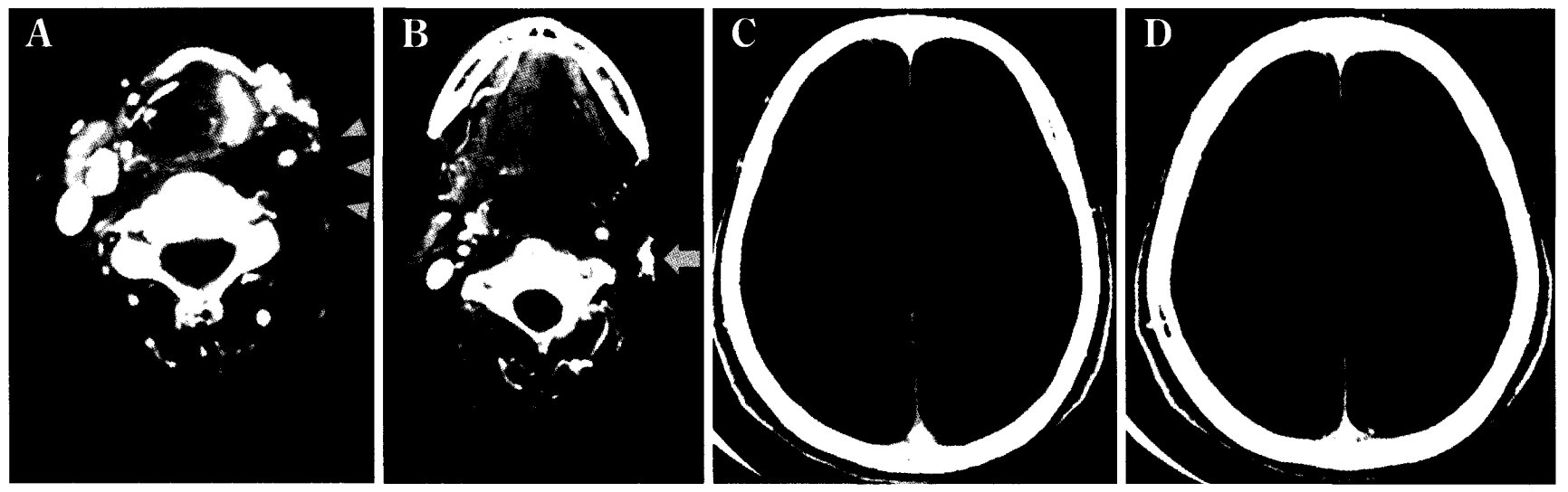

Fig. 1 Contrast-enhanced neck CT scans revealed the atrophy of the right sternocleidomastoid muscle (A, arrow heads) and exposure of the left carotid artery (arrow) with the partial skin defect (B). Plain CT scans showed a hypodensity territory in the left parietal lobe indicating previous cerebral infarction (C, D).
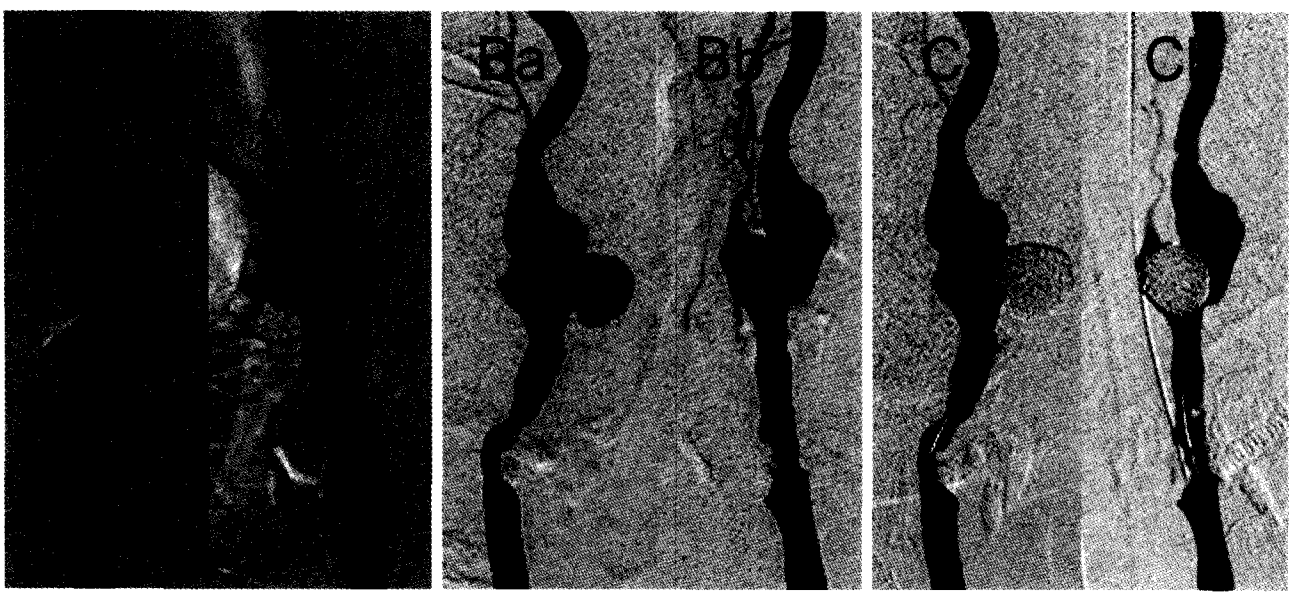

Fig. 2 Left common carotid injection. A-P view (a) and lateral view (b)

A : Angiogram obtained 5 years ago showing the aneurysm with the adjacent wall irregularity.

B : Pre-embolization. A new bleb-like bulging was detected laterally projecting from the aneurysm.

C : Post-embolization of the aneurysm. 
Fig. 3 Macrofindings (A), plain A-P film (B) and lateral angiogram (C)

Coils could be directly seen at the skin defect (A, white arrow), unraveled (B, black arrow) and extruded outside of the carotid artery (C, arrow head).
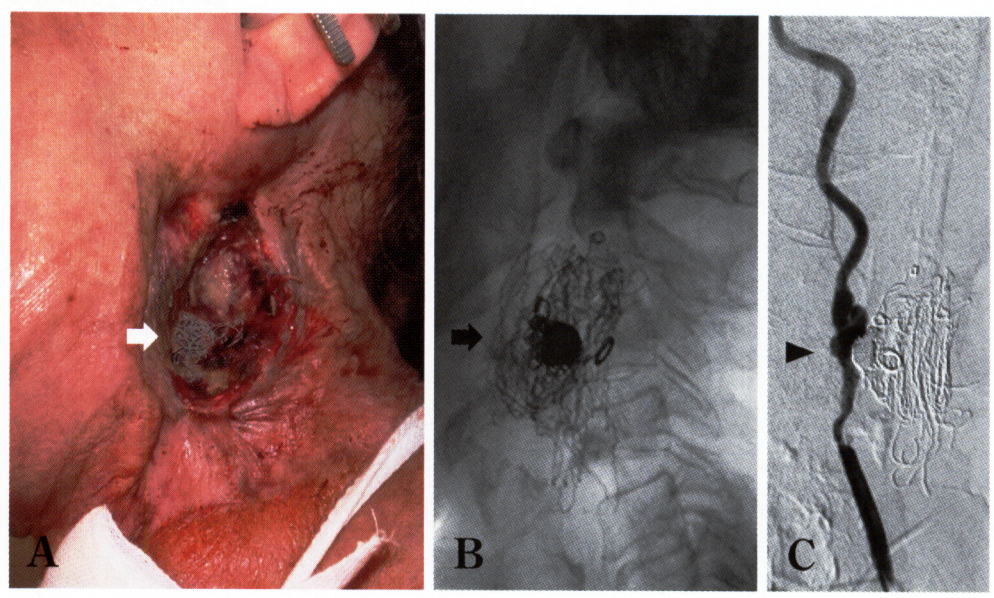

血管造影と閉塞試験（balloon occlusion test：BOT）を施 行したが, 術中に脳梗塞を併発し, 右麻痺・失語が出現 したため処置を中断した経緯があった。

その後, しばらく安定していたが, 78 歳になり再出血 を起こし, 入退院を繰り返した. 79 歳時, 外来受診中に 大量出血があり緊急入院となった。用手圧迫にて止血が 得られ, 輸血を施行するも, 翌日も数回の大量出血があっ たため,この時点で初めて脳神経外科にコンサルトされ た.

画像所見：頝部は，皮膚欠損と筋萎縮を伴い (Fig. 1A), 頝動脈が外表に露出している状態を, 造影 CT でも確認 できた (Fig. 1B)。頭部 CT では, 左前頭頭頂葉の陳旧性 脳梗塞を認めた（Fig. 1C，D）。血管造影所見では，第 3 頚椎レベルに動脈瘤が認められ, 近傍の動脈全体が不整 な狭窄/拡張を示しており, 動脈全体が放射線障害を受け ている可能性が強く示唆された（Fig. 2B）。瘤は，一部 その形状に若干の変化はあるものの, ほぼ同形同大で 5 年前から存在していた（Fig. 2A）.

治療所見: 放射線治療後で周囲組織の癒着と萎縮が激 しく, さらに皮膚欠損部の慢性感染を生じているため, 耳鼻科からは直達術による止血は困難との意見であった ので, 瘤内塞栓術を選択した。前回の他科で施行された 閉塞試験では, 虚血性合併症にて中断となり, 虚血而性 が不明であったため，できるだけ親動脈を温存すべきで あると考えた。全身麻酔下, Guglielmi detachable coils (GDC，Boston Scientific）11 本にてタイトなパッキング が得られ，止血が確認された（Fig. 2C）。翌日よりシロ スタゾール $200 \mathrm{mg} /$ day 内服を開始した。

経 過: 瘤内塞栓術後, 再出血なく経過していたが, 治療後 2 週間目に再出血を認めシロスタゾールを中止 した。この際，体表の皮膚欠損部からコイルが露出して いるのが確認できた（Fig. 3A）。血管造影ではコイル塊

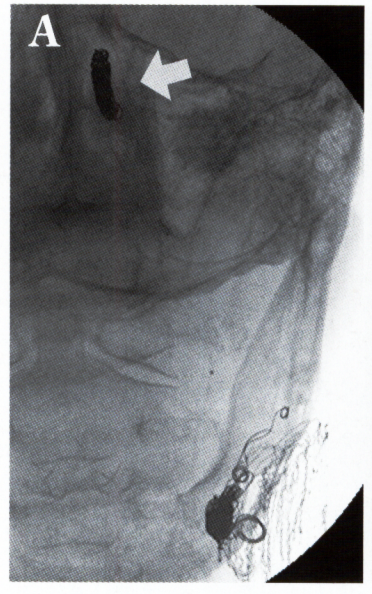

\section{B}

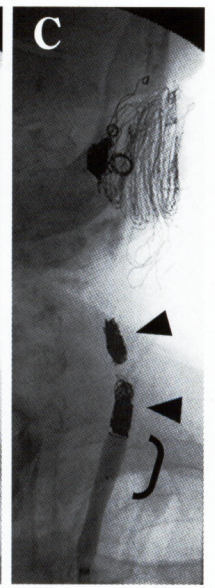

Fig. 4 Carotid angiogram A-P view of the re-treatment

The distal internal carotid artery was packed with coils tightly (A, arrow). And then, two separate coil masses (arrow heads) and a detachable balloon (bracket) were placed at the proximal site $(\mathbf{B}, \mathbf{C})$.

の外側半分が離散し, 皮膚欠損部側へ破裂しており（Fig. 3B，C), 緊急で endovascular trapping に踏み切った。最 初に遠位をしつかり塞栓し（Fig. 4A），近位は 2 つのコ イル塊と gold valve detachable balloon (GVB, Ingenor) を用いて閉塞した（Fig. 4B，C）。翌日に頝部皮膚欠損部 の圧迫止血部を解除すると, 離散したコイルの近位部に, 新たにコイルおよびバルーンを詰めた総頝動脈も一部露 出しており, 同部の放射線性壁損傷も危惧されたために, 後日，念のため鎖骨上窩で総䅡動脈を露出し結紮した。 新たな神経症状や画像上の梗塞所見は認めず，老人施設 へ転院となった。その後約 1 年経過するが再出血は認め ていない. 

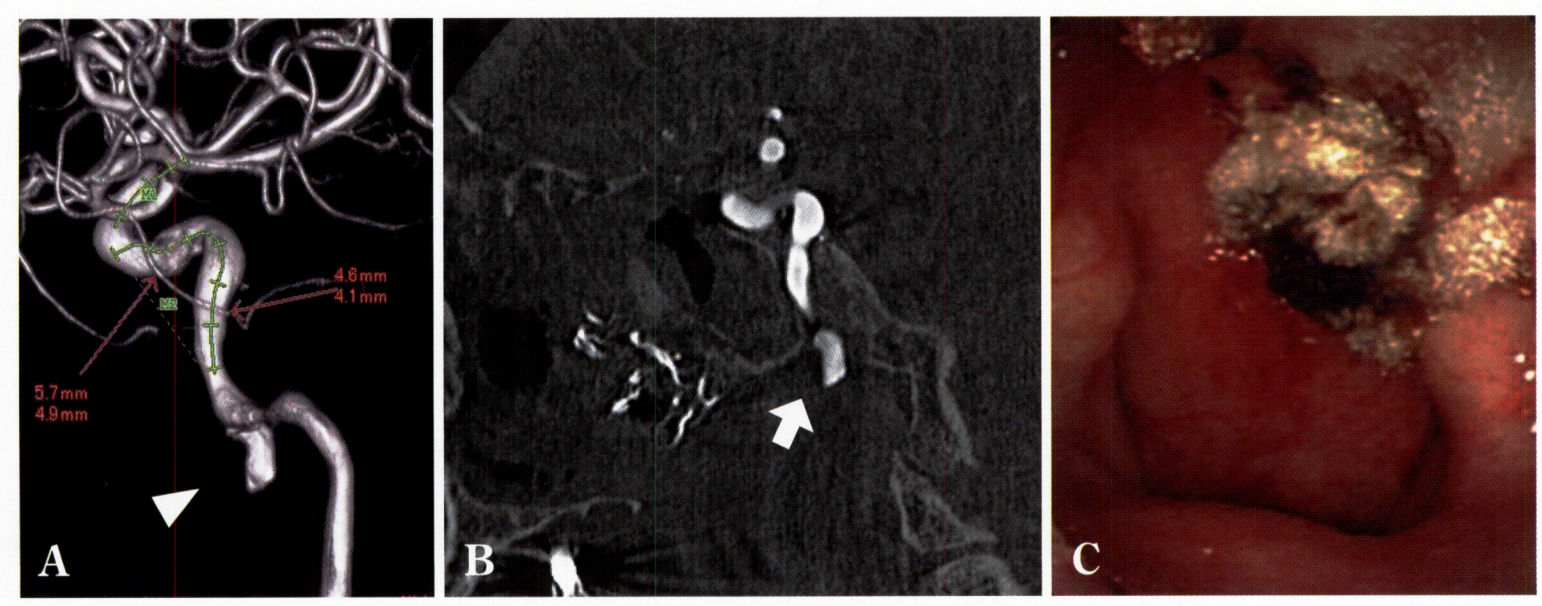

Fig. 5 Internal carotid angiogram (A) and contrast-enhanced CT scan (B) before treatment depicted an aneurysmal formation ( $\mathbf{A}$, arrow head) out of the petrous bone (B, arrow). Endoscopy showed the bleeding point of the aneurysm protruding into the pharynx (C).

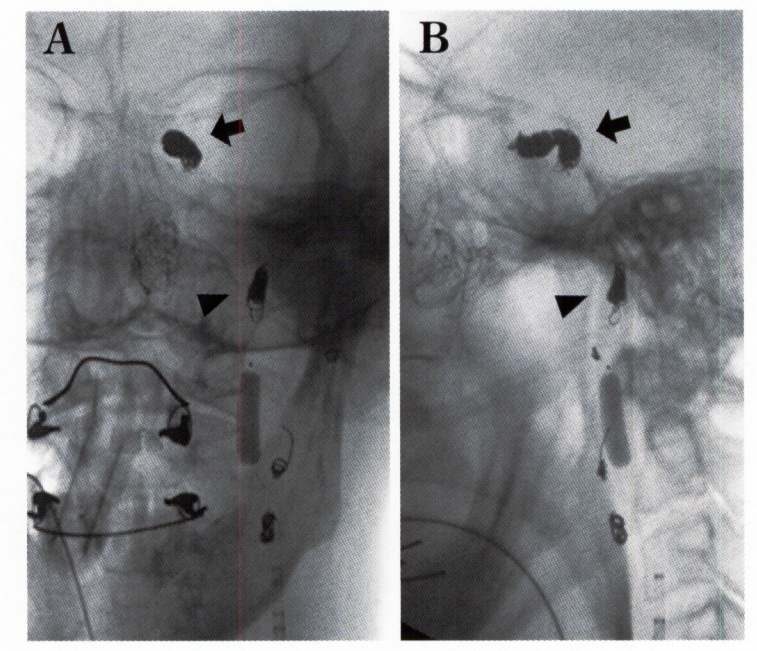

Fig. 6 Carotid angiogram after endovascular trapping. A-P view (A) and lateral view (B).

The distal coil mass (arrow) at the cavernous portion of ICA, and the proximal coil mass (arrowhead) at the cervical potion with a detachable balloon.

\section{【症例 2】}

患 者: 60 歳, 男性

既往歴：57 歳時に繰り返す鼻出血があり，当院耳鼻咽 喉・頭頸部外科を受診したところ, 左蝶形骨洞から両鼻 腔に伸展する $50 \times 27 \times 50 \mathrm{~mm}$ の腫瘍を指摘された. 生検 組織の病理診断は嗅神経芽腫 Grade II であり, 重粒子線 療法が施行された（炭素イオン線, 局所, $60.8 \mathrm{GyE} / 16$ 回/4 週).

現病歴: 59 歳時に, 左鼻腔より大量の鼻出血をきたし 入院となった。
画像所見：血管造影（Fig. 5A），造影 CT（Fig. 5B）打 よび鼻咽頭ファイバースコープ検査（Fig. 5C）にて鼻腔 内へ突出した動脈瘤が認められた。

治療所見: 左内頝動脈の閉塞試験では虚血耐性ありと 判断され，母動脈塞栓を選択した。全身麻酔下，GDC (Boston Scientific) と GVB (Ingenor) を用いて動脈瘤の 遠位と近位にて左内頝動脈を塞栓した（Fig. 6)。術直後 よりヘパリン 10,000 unit/day 点滴静注を行い, 翌日より シロスタゾール $200 \mathrm{mg} / \mathrm{day}$ 内服を開始し, 術後新たな 神経症状は認めなかった。

臨床経過：鼻出血はなくなり, 約 1 年のフォローアッ プ期間中, 再出血も神経学的症状の変化も認めていない.

\section{考 察}

今回の病態のような, 澒動脈の体表・体腔への破裂大 量出血は, 一般に CBS もしくはCAR と呼ばれ, その予 後は mortality $(40 \%)$, morbidity $(60 \%)$ と非常に不良 であることが知られている ${ }^{899)}$. また病院に到着する前に 亡くなってしまう例も多いと推測され, 現実の予後はさ らに不良と考えられる。幸運にも治療までたどり着けた 場合でも $40 \%$ 前後に再発を認め, $20 \%$ に永続的な神経症 状の出現を認めている ${ }^{9)}$.

放射線治療後, 年余を経て起こるCBS は, 単純に仮 性動脈瘤で説明される傾向があるが6), 病態はより複雑 であり, 中膜弾性板の断裂や内膜下の血管新生などの照 射域全体の慢性血管壁変性と, 壁構造が欠如した仮性動 脈瘤部分が混在した病態と捉える必要がある4)7). 特に出 血急性期の場合は, 両者の部位的な判別が困難である. 
Table 1 Reported cases of device extrusion after endovascular treatment for CBS

\begin{tabular}{|c|c|c|c|c|c|c|c|c|c|}
\hline $\begin{array}{l}\text { Author } \\
\text { (years) }\end{array}$ & $\begin{array}{l}\text { Age } \\
\text { Sex }\end{array}$ & $\begin{array}{l}\text { Primary } \\
\text { disease }\end{array}$ & $\begin{array}{l}\text { (1)Tx for } \\
\text { primary } \\
\text { disease }\end{array}$ & $\begin{array}{l}\text { (2)CBS } \\
\text { symptoms }\end{array}$ & $\begin{array}{l}\text { (3)T } \mathrm{T} \text { for } \\
\text { first CBS* }\end{array}$ & $\begin{array}{l}\text { (4)Tx for } \\
\text { device extr/ } \\
\text { recurrent CBS }\end{array}$ & $\begin{array}{l}\text { Extruded } \\
\text { site }\end{array}$ & $\begin{array}{l}\text { Period } \\
\text { between } \\
\text { (1) \& (2), } \\
\text { (3) \& (4) }\end{array}$ & $\begin{array}{l}\text { Outcome, } \\
\text { follow-up } \\
\text { period }\end{array}$ \\
\hline $\begin{array}{l}\text { John } \\
\text { (1993) }\end{array}$ & $\begin{array}{l}55 \\
\mathrm{M}\end{array}$ & $\mathrm{NPCa}$ & RT & $\begin{array}{l}2 \mathrm{w} \text { of } \\
\text { othemorrhea }\end{array}$ & iAn coils & $\begin{array}{l}\text { additional } \\
\text { iAn coils }\end{array}$ & ear canal & $\begin{array}{l}5 \mathrm{y}, \\
5 \mathrm{~d}\end{array}$ & $\begin{array}{l}\text { DO CBS, } \\
24 \mathrm{~d}\end{array}$ \\
\hline $\begin{array}{l}\text { Collignon } \\
(2003)\end{array}$ & $\begin{array}{r}78 \\
\mathrm{~nm}\end{array}$ & $\begin{array}{l}\mathrm{NPCa} / \mathrm{ICA} \\
\text { stenosis } \dagger\end{array}$ & $\begin{array}{l}\text { S, RT/ } \\
\text { CEA }\end{array}$ & $\begin{array}{l}\text { asymptomatic } \\
\text { An formation }\end{array}$ & $\begin{array}{l}\text { iAn coils } \\
\& \text { stents }\end{array}$ & $\begin{array}{l}\text { coil removal/ } \\
\text { CA PBO } \ddagger\end{array}$ & neck & $\begin{array}{l}8 \mathrm{y} \dagger \\
2 \mathrm{y} \ddagger\end{array}$ & $\begin{array}{l}\mathrm{nm}, \\
\mathrm{nm}\end{array}$ \\
\hline $\begin{array}{l}\text { Simental } \\
(2003)\end{array}$ & $\begin{array}{c}69 \\
\mathrm{~F} \\
\end{array}$ & $\begin{array}{l}\text { unspecified } \\
\text { malignancy }\end{array}$ & S, RT & $\begin{array}{l}\text { bleeding } \\
\text { from CCA }\end{array}$ & $\begin{array}{l}\text { CCA } \\
\text { covered stent }\end{array}$ & $\begin{array}{l}\text { flap } / \mathrm{CCA} \\
\text { trap coils }\end{array}$ & $\begin{array}{l}\text { infected } \\
\text { wound }\end{array}$ & $\begin{array}{l}48 \mathrm{y}, 3 \mathrm{w} \\
+24 \mathrm{~d} \uparrow \\
\end{array}$ & $\begin{array}{l}\text { DO stroke, } \\
\text { 2d }\end{array}$ \\
\hline $\begin{array}{l}\text { Simental } \\
(2003)\end{array}$ & $\begin{array}{l}47 \\
\mathrm{M}\end{array}$ & $\begin{array}{l}\text { lingual } \\
\mathrm{Ca}\end{array}$ & $\begin{array}{l}\text { chemo, } \\
\text { RT }\end{array}$ & $\begin{array}{l}\text { bleeding } \\
\text { from CCA }\end{array}$ & $\begin{array}{l}\text { CCA \& ICA } \\
\text { covered stent }\end{array}$ & $\mathrm{nm} / \mathrm{NR}$ & neck & $\begin{array}{l}\mathrm{nm}, \\
2 \mathrm{~m}\end{array}$ & $\begin{array}{l}\text { DO Ca, } \\
\mathrm{nm}\end{array}$ \\
\hline $\begin{array}{l}\text { Chow } \\
(2004)\end{array}$ & $\begin{array}{l}70 \\
\mathrm{M}\end{array}$ & $\mathrm{NPCa}$ & $\mathrm{RT}$ & $\begin{array}{l}7 \mathrm{~m} \text { of } \\
\text { othemorrhea }\end{array}$ & $\begin{array}{l}\text { iAn coils } \\
\& \text { stent }\end{array}$ & $\begin{array}{l}\text { cutting extruded } \\
\text { wire/NR }\end{array}$ & ear canal & $\begin{array}{l}7 \mathrm{y}, \mathrm{nm} \\
(>1 \mathrm{w})\end{array}$ & $\begin{array}{l}\text { good, } \\
1.5 \mathrm{y}\end{array}$ \\
\hline $\begin{array}{l}\text { Kiyosue } \\
(2004)\end{array}$ & $\begin{array}{l}58 \\
\mathrm{M}\end{array}$ & $\mathrm{NPCa}$ & $\begin{array}{l}\text { chemo, } \\
\text { RT }\end{array}$ & $\begin{array}{l}\mathrm{d} \text { of epistaxis } \\
\& \text { otorrhagia }\end{array}$ & $\begin{array}{l}\text { ICA trap } \\
\text { coils }\end{array}$ & $\begin{array}{l}\text { re-embolization } \\
\text { (ECA trap coils) }\end{array}$ & $\begin{array}{l}\text { ear canal } \\
\& \text { pharynx }\end{array}$ & $\begin{array}{l}17 \mathrm{y}, \\
14 \mathrm{~m}\end{array}$ & $\mathrm{~nm}$ \\
\hline $\begin{array}{l}\text { Shin } \\
(2005)\end{array}$ & $\begin{array}{l}32 \\
\mathrm{~F}\end{array}$ & $\mathrm{NPCa}$ & $\begin{array}{l}\text { chemo, } \\
\text { RT }\end{array}$ & epistaxis & $\begin{array}{l}\text { ICA trap } \\
\text { coils }\end{array}$ & $\mathrm{nm} / \mathrm{nm}$ & nostril & $\begin{array}{l}\mathrm{nm}, \\
\mathrm{nm}\end{array}$ & $\mathrm{nm}$ \\
\hline $\begin{array}{l}\text { Iguchi } \\
(2007)\end{array}$ & $\begin{array}{l}63 \\
\mathrm{M}\end{array}$ & SCCa & $\begin{array}{l}\text { chemo, } \\
\text { RT, S }\end{array}$ & $\begin{array}{l}\text { asymptomatic } \\
\text { An formation }\end{array}$ & $\begin{array}{l}\text { iAn coils } \\
\& \text { stent }\end{array}$ & $\begin{array}{l}\text { cutting extruded } \\
\text { wire/NR }\end{array}$ & $\begin{array}{l}\text { hypo- } \\
\text { pharynx }\end{array}$ & $\begin{array}{l}2 \mathrm{y} 3 \mathrm{~m}, \\
2 \mathrm{y}\end{array}$ & $\begin{array}{l}\text { good, } \\
\mathrm{nm}\end{array}$ \\
\hline $\begin{array}{l}\text { Zhuang } \\
(2007)\end{array}$ & $\begin{array}{l}49 \\
\mathrm{M} \\
\end{array}$ & $\begin{array}{l}\text { sinus } \\
\text { infection }\end{array}$ & $\begin{array}{l}\text { endo } \\
\text { sinus S }\end{array}$ & epistaxis & iAn coils & $\begin{array}{l}\text { coil removal/ } \\
\text { ICA sacrifice }\end{array}$ & nostril & $\begin{array}{l}\text { during } \mathrm{S} \text {, } \\
2 \mathrm{y}\end{array}$ & $\mathrm{nm}$ \\
\hline $\begin{array}{l}\text { Roh } \\
(2008)\end{array}$ & $\begin{array}{l}62 \\
\mathrm{M} \\
\end{array}$ & $\begin{array}{l}\text { transglottis } \\
\text { SCCa }\end{array}$ & $\begin{array}{l}\text { RT, S, } \\
\text { chemo }\end{array}$ & $\begin{array}{l}\text { bleeding } \\
\text { from CCA }\end{array}$ & $\begin{array}{l}\text { covered } \\
\text { stent }\end{array}$ & $\begin{array}{l}\text { ICA \& ECA } \\
\text { ligation }\end{array}$ & $\begin{array}{l}\text { infected } \\
\text { wound }\end{array}$ & $\begin{array}{l}2 \mathrm{y} 3 \mathrm{~m}, \\
\mathrm{~nm}\end{array}$ & $\begin{array}{l}\mathrm{DO} C \mathrm{Ca} \\
4 \mathrm{~m}\end{array}$ \\
\hline $\begin{array}{l}\text { Roh } \\
(2008)\end{array}$ & $\begin{array}{l}85 \\
\mathrm{M} \\
\end{array}$ & $\begin{array}{l}\text { supraglottis } \\
\text { SCCa }\end{array}$ & $\mathrm{RT}, \mathrm{S}$ & $\begin{array}{l}\text { bleeding from } \\
\text { CCA \& ICA }\end{array}$ & $\begin{array}{l}\text { CCA trap } \\
\text { coils }\end{array}$ & $\begin{array}{l}\mathrm{CCA} \\
\text { ligation }\end{array}$ & $\begin{array}{l}\text { infected } \\
\text { wound }\end{array}$ & $\begin{array}{l}10 \mathrm{~m} \\
\mathrm{~nm}\end{array}$ & $\begin{array}{l}\mathrm{DO} \mathrm{Ca} \\
8 \mathrm{~m}\end{array}$ \\
\hline $\begin{array}{l}\text { Roh } \\
(2008)\end{array}$ & $\begin{array}{l}53 \\
\mathrm{M} \\
\end{array}$ & $\mathrm{NPCa}$ & $\begin{array}{l}\text { chemo, } \\
\text { RT }\end{array}$ & $\begin{array}{l}\text { bleeding } \\
\text { from CCA }\end{array}$ & $\begin{array}{l}\text { CCA trap } \\
\text { coils }\end{array}$ & $\begin{array}{l}\mathrm{CCA} \\
\text { ligation } \\
\end{array}$ & $\begin{array}{l}\text { infected } \\
\text { wound }\end{array}$ & $\begin{array}{l}11 \mathrm{y} 10 \mathrm{~m}, \\
\mathrm{~nm}\end{array}$ & $\begin{array}{l}\text { good, } \\
12 \mathrm{~m}\end{array}$ \\
\hline $\begin{array}{l}\text { Roh } \\
(2008)\end{array}$ & $\begin{array}{l}64 \\
\mathrm{M} \\
\end{array}$ & $\begin{array}{l}\text { tonsil } \\
\text { SCCa }\end{array}$ & S, RT & $\begin{array}{l}\text { bleeding } \\
\text { from ECA }\end{array}$ & $\begin{array}{l}\text { ECA trap } \\
\text { coils }\end{array}$ & $\begin{array}{l}\text { re-embolization } \\
\text { (ICA \& CCA trap coils) }\end{array}$ & $\begin{array}{l}\text { infected } \\
\text { wound }\end{array}$ & $\begin{array}{l}44 \mathrm{~m}, \\
\mathrm{~nm}\end{array}$ & $\begin{array}{l}\text { good, } \\
12 \mathrm{~m}\end{array}$ \\
\hline $\begin{array}{l}\text { Lin } \\
(2010)\end{array}$ & $\begin{array}{l}55 \\
\mathrm{M} \\
\end{array}$ & $\begin{array}{l}\text { oropharyn- } \\
\text { geal SCCa }\end{array}$ & $\begin{array}{l}\mathrm{S}, \mathrm{RT} \\
\text { chemo }\end{array}$ & $\begin{array}{l}\text { transoral } \\
\text { hemorrhage }\end{array}$ & $\begin{array}{l}\text { ECA, ICA \& } \\
\text { CCA trap coils }\end{array}$ & $\begin{array}{l}\text { carotid sheath } \\
(\mathrm{CA} \& \mathrm{JV}) \text { ligation }\end{array}$ & $\begin{array}{l}\text { neck \& } \\
\text { pharynx }\end{array}$ & $\begin{array}{l}3 \mathrm{y}, \\
\mathrm{nm}\end{array}$ & $\begin{array}{l}\text { good, } \\
18 \mathrm{~m}\end{array}$ \\
\hline $\begin{array}{l}\text { Our case } \\
(2010)\end{array}$ & $\begin{array}{l}80 \\
F\end{array}$ & $\begin{array}{l}\text { unspecified } \\
\text { neck } \mathrm{Ca}\end{array}$ & $\mathrm{S}, \mathrm{RT}$ & $\begin{array}{l}\text { bleeding } \\
\text { from neck }\end{array}$ & iAn coils & $\begin{array}{l}\text { ICA \& CCA trap } \\
\text { coils, CCA PBO, } \\
\text { CCA ligation }\end{array}$ & neck & $\begin{array}{l}36 \mathrm{y}, \\
14 \mathrm{~d}\end{array}$ & $\begin{array}{l}\text { good, } \\
\text { ly }\end{array}$ \\
\hline
\end{tabular}

extr : extrusion, $y:$ years, $\mathrm{m}:$ months, $\mathrm{d}:$ days, $\mathrm{nm}:$ not mentioned, $\mathrm{Tx}:$ treatment, $\mathrm{Ca}:$ carcinoma, $\mathrm{SCCa}:$ squamous cell carcinoma, NPCa: nasopharyngeal carcinoma, RT: radiation therapy, S: surgery, Chemo: chemotherapy, CEA: carotid endarterectomy, An : aneurysm, iAn : intraaneurysmal, trap : trapping, PBO : permanent balloon occulusion, $\mathrm{CA}$ : carotid artery, CCA : common carotid artery, ICA : internal carotid artery, ECA : external carotid artery, JV : jugular vein, $\mathrm{DO}$ : died of, NR: device extruded with no recurrent CBS for reasons such as auto-thrombosis or effective embolization, * : subsequently extruded device, $\dagger:$ ICA stenosed $6 \mathrm{y}$ after RT (2y before CBS), $\$:$ stent and balloon also extruded $4 \mathrm{~m}$ after coil extr, $\uparrow:$ CBS followed $24 \mathrm{~d}$ after stent extr

放射線照射後に血管破裂を生じた動脈は，破裂した部の みならず，照射野全体に壁の脆弱化が進行していると考 えるべき477で，このような血管に異物を留置すること は，かえつて炎症を惹起しデバイスの露出および留置部 血管の破裂を誘発させる可能性がある（Table 1）ため, できるだけ照射野外での母動脈塞栓を目指すべきと考え られる、症例 1 では母動脈塞栓術後, 照射野にコイルが 留置されていたため, 瘤内塞栓術後と同様な再出血が生
じる可能性があり，完全に照射野から外れた鎖骨上窩に 小切開を設け，直視下に結禁を追加した。常にバイパス 術ができる施設でさえ，大量出血でショック状態にある ような場合, 緊急の血行再建手術はリスクが高い.また, カバー付きステントは, 非常に魅力的な選択肢であるが, 本邦での保険適応はなく，高率な内腔閉塞が報告9)11)さ れており，真の有効性は不明である。

症例 2 のように時間的余裕があり，閉塞試験にて母動 
脈閉塞が可能と判定される場合は，照射野外での endovascular trapping でよいが，虚血耐性がない場合が問題 となる．大量出血が続く状況下で，一時的にでも止血を 得て時間を稼ぐために, 瘤内塞栓術を行うことは有用な 方法とも考えられる文 4)8)13). しかし，これにて永続的 閉塞を期待することには無理があり, 可及的速やかにバ イパス術を検討すべきである ${ }^{12)}$. 現実には同側の頝部に 広範な照射が行われており，外頝動脈も放射線障害が生 じているため, ドナー動脈をどこから誘導するかは大き な問題である。 また多くの場合，皮膚欠損のため頝部に 広範な結合組織感染を伴っていることも, 治療のハード ルを上げている。

疾患が非常に高い致命率を有することを鑑みると，永 続的動脈閉塞により脳梗塞のリスクがあると推定される 場合でも，救命目的に母動脈閉塞を行うことは，現時点 では妥当な選択肢と考えられる。

\section{結 語}

今回，頝部腫瘍に対する放射線治療後，各 36 年と 2 年の経過で大量出血にて発症した CBS の 2 症例を報告 した，緊急性が高く，治療困難な疾患であるが，照射野 外での endovascular trapping による母動脈塞栓により救 命可能な場合があり, 現時点では妥当な治療法であると 考えられた。

\section{文 献}

1) Chow MW, Chan DT, Boet R, Poon WS, Sung JK, Yu SC: Extrusion of a coil from the internal carotid artery through the middle ear. Hong Kong Med J 10:215-216, 2004.

2) Collignon FP, Friedman JA, Piepgras DG, Nichols DA, Cloft $\mathrm{H}$ : Transcutaneous coil, stent, and balloon migration following endovascular treatment of a cervical carotid artery aneurysm. J Neurosurg 98: 1135, 2003.

3) Iguchi H, Takayama M, Kusuki M, Nakamura A, Kanazawa A, Hachiya K, Yamane H: Transmucosal coil migration after endovascular management for carotid artery pseudoaneurysm: A late complication Acta Otolaryngol 127: 447-448, 2007.

4) John DG, Porter MJ, van Hasselt CA: Beware bleeding from the ear. J Laryngol Otol 107: 137-139, 1993.

5) Kiyosue H, Okahara M, Tanoue S, Sagara Y, Matsumoto S, Mori H, Arita M, Watanabe T, Suzuki M: Dispersion of coils after parent-artery occlusion of radiation-induced internal carotid artery pseudoaneurysm. AJNR Am J Neuroradiol 25: 1080-1082, 2004.

6) Lesley WS, Chaloupka JC, Weigele JB, Mangla S, Dogar MA: Preliminary experience with endovascular reconstruction for the management of carotid blowout syndrome. AJNR Am J Neuroradiol 24: 975-981, 2003.

7) Lin HW, Tierney HT, Richmon JD, Mark EJ, Deschler DG: Extrusion of embolization coils through the carotid artery in a radiated neck. Auris Nasus Larynx 37:390393, 2010.

8) Mazumdar A, Derdeyn CP, Holloway W, Moran CJ, Cross DT 3rd: Update on endovascular management of the carotid blowout syndrome. Neuroimaging Clin N Am 19: 271-281, 2009.

9) Roh JL, Suh DC, Kim MR, Lee JH, Choi JW, Choi SH, Nam SY, Kim SY: Endovascular management of carotid blowout syndrome in patients with head and neck cancers. Oral Oncol 44:844-850, 2008.

10) Shin YS, Kim SY, Moon SK: Intranasal extrusion of the endovascular coil after occluding internal carotid artery for massive nasopharyngeal bleeding. Otolaryngol Head Neck Surg 133: 644, 2005.

11) Simental A, Johnson JT, Horowitz M: Delayed complications of endovascular stenting for carotid blowout. $A m \mathrm{~J}$ Otolaryngol 24: 417-419, 2003.

12) Toyoda $T$, Sawatari $K$, Yamada $T$, Kaneko $H$, Yamashita $T$, Taniuchi $\mathrm{N}$ : Endovascular therapeutic occlusion following bilateral carotid artery bypass for radiation-induced carotid artery blowout. Radiat Med 18:315-317, 2000.

13) Zhuang Q, Buckman CR, Harrigan MR: Coil extrusion after endovascular treatment. J Neurosurg 106:512, 2007. 
Carotid Blowout Syndrome に対する血管内治療

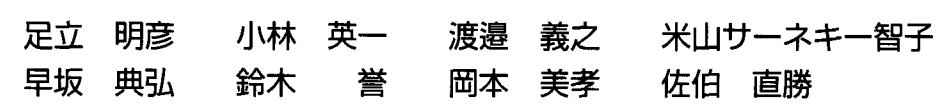

CBS（carotid blowout syndrome）は，頭䅡部腫瘍に対する放射線治療後に，遅発性に動脈破裂を きたす致死的疾患として知られている. 今回，放射線治療後 36 年および 2 年を経て大量出血で発症 し，血管内治療で良好な結果が得られた 2 例を報告する. 1 例目は，瘤内塞栓をしたものの， 2 週間 後に再出血し，母動脈を閉塞した. 2 例目は，虚血耐性を確認できたため，同様に trapping にて止血 を得た。

大量出血で発症する CBS は緊急の止血処置を要する，将来的には膜付きステントに期待が寄せら れるが，現時点では閉塞試験が不可能な際にも，救命目的に母動脈閉塞を要する場面は少なくない. その際，照射野を外しての endovascular trapping は永続的止血を得る確実な方法であり，有効と考 えられた.

脳外誌 $20: 597-603,2011$

Editorial Comment

\section{Carotid Blowout Syndrome：緊急かつ適切な治療が求められる病態}

\section{川崎医科大学脳神経外科 宇野昌明}

近年䅡部悪性疾患の治療成績が向上し, 長期生存 例が多くみられるようになった。 それに伴って同部 位の放射線治療後に頝動脈の狭窄および閉塞症例, あるいは頝動脈の破綻による出血例の報告がみられ るようになった。著者らはこの中で, 放射線治療後 の Carotid Blowout Syndrome に対する血管内治療の 有効性について述べている. 非常に治療の難しい 2 症例に対して予後良好な結果を示し, 貴重な症例報 告であると思われる。特に症例 1 では頝動脈からの 出血例に対して緊急で血管内治療を行い, かつその 後も再出血をきたし, 治療に難渋した症例を提示し ている.この症例でみられたように多くの症例では 総頝動脈を中心に動脈が脆弱化しており，いったん 止血されても再破裂する症例が多くみられる。血管
内治療でどの部位を閉塞すべきか, 閉塞時に脳虚血 の耐性があるかどうかなど不確定要素が多く, 治療 の決め手がないのが現状である．著者が述べている ように外科的に正常な総䅡動脈の近位部と遠位部を みつけて trap あるいは血管置換術を行うのが確実 であるが，緊急時に施行することが難しいことが多 い.コイル塞栓術以外にはカバー付きステントによ る補強が今後有力な治療法となると考光られる。し かしこの方法も論文で述べているようにステント内 閉塞や感染の危険性をどう防止するかが今後の課題 である. 1 施設では経験する症例数が限られるので, 多施設で症例を集積し, 耳鼻科や外科とも共同で最 良の治療方法の選択, および中長期予後の検討が必 要となろう。 